UDC 94:327.151.3-054.73.](4-6€C)“2015/2016”

DOI https://doi.org/10.32838/2663-5984/2020/4.31

Podrez Yu.V.

Sumy State Pedagogical University named after A.S. Makarenko

Yarosh N.V.

Sumy State Pedagogical University named after A.S. Makarenko

\title{
MIGRATION POLICY OF THE MEMBER STATES OF THE EUROPEAN UNION REGARDING THE SETTLEMENT OF REFUGEE PROBLEMS IN 2015-2016
}

The article examines the political consequences of the migration crisis of 2015-2018 for EU member states, which is caused by the massive influx of migrants to Europe from the war-torn countries of Africa and the Middle East. Its consequences in some way potentially threaten the unity of the EU and may negatively affect the process of European integration. The main focus of this study is on the analysis of their own migration policies of EU member states to resolve refugee problems (in particular, Germany, Hungary, France, Denmark, the Netherlands, etc.), which has led to local political conflicts and contradictions. Most countries try to limit the risks associated with migration. Strategically, these actions are actually reduced to three points: effective border protection, control of the influx of foreigners into the country, as well as adequate integration policy.

The analysis of migration policy directly by EU countries in relation to refugees during the period we have indicated shows a sharp change in the attitude of the local population - from open door policy to closing borders. The system of cooperation between states within the European Union and the Council of Europe on refugees and migration in general is the most developed. The combination of EU and Council of Europe migration law allows more or less control over the flow of refugees, asylum seekers and illegal migrants, defines unified decision-making procedures for granting refugee status and the right to asylum, and cooperates with as many European continents as possible, joining forces to address any refugee issues. This, in our opinion, is due to the growing number of arrivals, disputes about the nature of the observed migration flows, as well as fears of Islamization, rising crime and terrorist threats.

Key words: migration, migration policy, European Union, migration crisis, refugees.

The European migration crisis, which arose in the mid-2010's, has become one of the biggest challenges for EU countries in the 21'st century. The influx of millions of refugees and economic migrants to wartorn Europe, as well as Iraq, Afghanistan, Libya and other countries in the Middle East and Africa, has caused a real humanitarian catastrophe that Europe has never known in its recent history.

The question of how to stop the flow of refugees from Syria and from the African continent was the impetus for consolidation and at the same time became a stumbling block for European countries. At present, they are forced to revise not only their national legislation, but also, first of all, the legislation of the European Union on the implementation of the common migration policy. The united Europe was not ready for a migration crisis of this magnitude.

Defining the European migration crisis of 2015-2018 as a phenomenon that causes changes in the existing system at many levels of its functioning, we can confidently say about the negative consequences that we observe as a result of this crisis. The massive influx of refugees into Europe has caused many problems both at the national level of individual states, which have met with dissatisfaction of the majority of the population with the existing migration policy, with interethnic conflicts and xenophobia and even terrorist acts, and at the supranational level in the European Union inability to fully implement all existing mechanisms for regulating refugee issues [9].

The purpose of the article is to analyze the internal migration policy of the EU countries and mechanisms for resolving the problems related to the influx of refugees.

Main material. Despite the common migration legislation of the European Union, the member countries of the organization began to pursue their own migration policies to address the problems of reception of refugees, which led to local political conflicts and contradictions. Thus, German Chancellor 
Angela Merkel pursues a liberal "open door" policy towards refugees and other categories of migrants, encouraging other countries to do so [5].

The refugee situation in Germany, according to representative opinion polls, "worries" almost half of the country's population. A similar situation was last observed in the winter of 2015-2016, during the refugee crisis. But if in 2015 almost 900 thousand refugees arrived in the country, who submitted tens of thousands of asylum applications every month, in the first half of 2018 in Germany only about 93,5 thousand such applications were submitted. For comparison only in August 2016, in one month, there were almost as many such statements - about 90 thousand. And compared to last year, the number of refugees in the country is steadily declining $-16,4$ percent less in six months this year than in the same period in 2017 [4].

The authors of the study link the "great unrest" of Germans with the dispute over refugee policy between Chancellor Angela Merkel and Interior Minister Horst Seehoferm in late June - early July 2018. It almost ended with the collapse of the government. Horst Seegoferm has threatened to resign from both the government and the head of the Christian Social Union (CSU), a conservative Bavarian party that is a traditional partner of Merkel, the Christian Democratic Union, if politicians do not agree in resolving the issue of receiving refugees [4].

The conflict erupted over a single sub-item of Seehofer's new master plan on migration policy: the minister's intention not to allow more refugees already registered in any other EU country into Germany and to return them immediately. In the end, Merkel agreed. But on one condition: readmission must take place with the consent of the country in which the migrant first found himself in the EU [7].

The following week, after reaching an agreement in Berlin, Seehofer met with his counterparts from other EU countries in Innsbruck, Austria. Representatives of only 11 EU countries agreed to take back "transit" refugees, although at the EU summit in late June, according to Chancellor Merkel, there were 14 more, and most importantly - neither Austria nor Italy. At the same time, it is from Italy, which is closest to the Mediterranean via Africa, that the flow of refugees to Germany transits through Austria.

The governments of both countries set preconditions for Berlin. Yes, Rome is ready to talk about readmission only after the European Union strengthens its external borders so that refugees have no chance to cross the Mediterranean. If this, as stated by the head of the Italian Interior Ministry Salvini, "big problem" is solved, then all the "small", which, in his opinion, includes, for example, a quota for the distribution of migrants in EU countries, will disappear by themselves [4; 7].

Liberalism in Merkel's views and actions on refugees has negatively affected the Chancellor's political image, and as of 2018 , only about $19 \%$ of voters supported her. According to a poll by Insa, about $39,9 \%$ of Germans consider Chancellor Angela Merkel's migration policy to be her weakness. The statistic confirms the warning of US President Donald Trump, who commented on the situation with differences of opinion in the German parliament as follows: "The German people are turning against their leaders, while migration is rocking the already fragile Berlin coalition. Crime in Germany was high. Made all over Europe - to let in a million people who have changed their culture so much and so violently!", said Trump in his Twitter [6].

Society is also outraged by the financial component of the issue. Thus, according to the Minister of Finance of Germany Olaf Scholz, by 2020 the country's budget has set aside 78 billion euros for the costs associated with the reception and resettlement of refugees [3].

The federal budget will cost about 70 billion euros, and eight billion will be allocated by local budgets. $€ 31$ billion will go to fight the causes of migration in the homeland of refugees, $€ 21$ billion will be spent on social benefits, $€ 13$ billion on measures to integrate migrants in Germany, and $€ 5,2$ billion on housing.

Instead, the Eurosceptic party "Alternative for Germany" (AfD) of entrepreneur Frauke Petri is gaining popularity, believing that "comprehensive control" is needed to prevent the emergence of new refugees in the country. The party even filed a complaint with the Constitutional Court against the migration policy of German Chancellor Angela Merkel. Among the Germans, the AfD leader was nicknamed "Adolfin", in honor of Reich Chancellor Adolf Hitler, for his overly extremist views on solving the refugee problem $[2 ; 5]$.

Flirting with the mood of Germans, dissatisfied with the increase in the number of refugees in the country, gives Eurosceptics a chance to take a strong position in the elections and radically change the political situation. Given that the migration crisis remains an urgent problem, enough Germans may vote for the AfD in the upcoming parliamentary elections in Germany. In the last regional elections, it came in second $(20,8 \%$ of citizens voted for the AfD), second only to the Social Democratic Party of Germany [2; 5].

On the other hand, Hungary, a country where Eurosceptics hold strong power, makes it clear to other 
European countries that EU supranational bodies have no right to decide for national governments whether to take refugees or not, and dictates its radical methods. It all started with the fact that in 2015 the Hungarian authorities refused to resettle refugees in their country at the request of the EU (after the introduction of the quota mechanism).

Radical problem of refugees in Hungary is solved by the leading conservative party "Fidesz - Hungarian Civil Union" of Prime Minister Viktor Orban, who has a reputation as a Eurosceptic. Hungary is the only EU member state to openly oppose Brussels. The Hungarian government is conducting an information campaign "Stop Brussels", along the state border with Serbia and Croatia, through the territory of which refugees are infiltrating Hungary, special fences are being built, equipped with video surveillance. According to Victor Orban, these fences will be able to withstand the influx of large crowds of refugees. Since the beginning of this year, 4 military bases have been built in Hungary from containers, where soldiers will be stationed to patrol the border areas and detain refugees in time for further deportation. In Hungary, new rules have been adopted to keep refugees in container camps [1].

The far-right Jobbik party is speculating on antiimmigrant sentiment, trying to increase its popularity in Hungarian society. Jobbik flirts with Russia, opposes EU and NATO integration. Representatives of this political force took part in the congress of far-right European parties in Russia. Jobbik is the third largest seat in parliament (23 seats), and $20 \%$ of Hungary's population voted for it in the 2014 elections [1].

The current Hungarian government makes it clear to the European Union that its citizens fear terrorist attacks in their cities and new social conflicts and are ready to spare no money in order to strengthen migration policy and strengthen their borders. Otherwise, the Eurosceptic Jobbik party may come to power, and this will be a new headache for the EU. Although the Hungarian government has been criticized by human rights organizations such as Human Rights Watch for its ill-treatment of refugees, some progress has been made in addressing the refugee problem. In 2016, out of 29,4 thousand applications for political asylum in Hungary, only 425 foreigners received (Germany accepted 280 thousand refugees in 2016).

The problem of refugees is no less acute in France and the Netherlands. The citizens of these states felt the effects of the migration crisis on their security. In 2016, there were 15 terrorist attacks in France. According to the Dutch Ministry of Security and Justice, about 40 terrorists arrived in the Netherlands in 2016.
Of these, only three IS-linked terrorists have been apprehended so far. In the Netherlands, the 4'th level of terrorist threat was declared on a 5-point scale [1].

Local Eurosceptics Marin Le Pen, leader of France's National Front party, and Geert Wilders, who heads the Dutch Freedom Party, have suggested the idea of de-Islamization as an alternative to the EU's current migration policy. They believe that if the country leaves the EU, it will be easier to solve a lot of problems that have accumulated, because the national authorities will not interfere in the internal affairs of France and the Netherlands. Politicians see Islam as a manifestation of totalitarianism and a threat to European civilization.

Geert Wilders believes that in order to resolve the migration crisis, the Dutch borders must first be closed to refugees and migrants from Muslim countries. Next, it is necessary to deal with Muslims inside the Netherlands - to deprive them of residence permits or refugee status. Wilders calls for the closure of all mosques, Muslim schools, refugee detention centers, and the prohibition of all manifestations of Islam, culture and self-expression by Muslims, including the Koran, in Dutch public life. He proposes to imprison all those suspected of involvement in Islamic extremism, deprive Dutch citizens of dual citizenship passports, with subsequent deportation to their "homeland" and not to allow citizens who took part in the fighting in Syria on the side of ISIS into the Netherlands. According to Wilders, these measures will help the Netherlands save 7,2 billion euros [10].

A more "soft" approach to de-Islamization is followed by Marine Le Pen. She believes that France has the right to impose restrictions on the reception of refugees up to 10 thousand people a year. Le Pen is convinced that France should abandon cheaper labor from abroad and introduce additional taxes for foreign workers. The leader of the National Front proposes to simplify the deportation mechanism and complicate the procedure for obtaining French citizenship for migrants. Dutch and French Eurosceptics are betting on bans that would make it uncomfortable for refugees and migrants to stay in their countries. Marine Le Pen's ideas have supporters in French society. Quite a few French people have a negative attitude towards the large number of foreigners in their country. According to the French publication The Local, about $57 \%$ of French people believe that France is oversaturated with migrants, who, according to $54 \%$ of respondents, change it for the worse.

In Denmark, there is a young party of Eurosceptics Ne Borgerlige ("New Order") by architect Pernil Vermund. Unlike the Eurosceptics of other countries, 
Vermund's approach to the refugee problem is more moderate and is based on an electoral approach. Vermund believes that Denmark can only grant political asylum to UN-directed refugees. A refugee worthy of living in Denmark must be able to take care of himself, have a profession, and find a job. Refugees who cannot take care of themselves should not be granted political asylum.

According to Pernil Vermund, Denmark should withdraw not only from the EU, but also from international legal instruments governing issues related to refugees: the "Convention relating to the Status of Refugees", the "Convention on the Reduction of Statelessness". In this way, Denmark will be able to remove the grounds for accepting refugees. The party Ne Borgerlige is present in 9 city and 1 regional administration, has offices in 51 settlements and intends to participate in the upcoming local and parliamentary elections [11].

These examples of the strengthening of the role of radical political forces in Europe are confirmed by the fact that the migration crisis in the EU will not be resolved until the governments of the member states strengthen the common migration policy. The security of its own citizens is a higher priority than the point of view of European officials regarding the reception of new refugees.

According to researchers, migration should not be considered a source of exceptional threats. Abstracting from specific threats, it can be qualified as a challenge that prompts to respond not one but two types: 1) to protect the security system in its former status and 2) to rebuild it, i.e. qualitative changes in the system.

It is the first approach - from the standpoint of threats - that finds expression in public policy, in particular in European countries. Suffice it to mention the Communiqué "A Common Immigration Policy for Europe: Principles, Measures and Tools", which was published by the European Commission in June 2008 [73]. Among the nine general principles for the development of a common immigration policy, three directly belonged to the category of "security":

- a visa policy that is in the interests of the EU, facilitating the entry of bona fide citizens and at the same time strengthening security measures;

- integrated border management to preserve the integrity of the Schengen area;

- introduction of strict measures to combat human trafficking, protection of victims, effective fight against illegal immigration and illegal employment, effective and efficient return policy of migrants, based on respect for fundamental rights and freedoms [14].
To summarize these principles, most states try to limit the risks associated with migration. Strategically, these actions are actually reduced to three points: effective border protection, control of the influx of foreigners into the country, as well as adequate integration policy.

The change in attitudes towards newcomers (from open door policy to border closure) is primarily due to the growing number of arrivals, disputes over the nature of observed migration flows, and this is fueled by some European policies - fear of Islamization, rising crime and terrorist threats. Thus, during the discussions on the problems that arose, two opposing approaches emerged to define the crisis in the context of security: 1) as challenges that need to be addressed in a timely manner, or 2) as threats that need to be addressed.

In the first approach, the crisis is seen as a problematic situation, which forms its tasks for the EU, EU member states, Turkey and other representatives of the international community - humanitarian organizations, the Middle East, including countries of reception, transit and origin of refugees. and migrants. The threat approach treats crises as negative impacts that are destructive to EU Member States and the EU as a whole, which is particularly important given the EU's goal of creating a security zone for Member States and their citizens. Proponents of interpreting the crisis through the categories of challenges are the European Commission, Germany, the Scandinavian countries. Instead, supporters of the opposite approach are the new EU members, among them the most active group is the so-called coalition of dissenters, which includes Hungary, Slovakia, the Czech Republic, Poland [56].

The impact of the migration crisis on security is manifested at the level of migrants (refugees), local communities, societies, individual states and the European Union as a whole. It applies to all dimensions of security: economic, socio-cultural, political and even military.

Paris, Brussels, Nice, Berlin, Manchester, London, Barcelona - European cities have become increasingly targeted by terrorists in recent years, and one of the reasons is the influx of terrorists into Europe under the pretext of refugees during the migration crisis, when migrant flows could not be controlled. Already in 2015, the number of victims of armed attacks across Europe increased to 267 people, and since the beginning of 2016, 172 Europeans have died as a result of terrorist attacks. Most people died in the terrorist attacks in Paris - 155 people, in second place - Nice, France, where 84 people died. So, in two years terrorist attacks in Europe took the lives 
of 443 people. The reason for these terrorist acts, committed by terrorists of the Islamic State and Al Qaeda, is related to the ridicule of the events in Syria by Europeans and Islamic values [57].

On November 13, 2015, a terrorist attack took place in Paris, killing about 130 people. Belgian Muslims are considered suspects. And on March 22, 2016, terrorists carried out another terrorist attack in Brussels. These two events have a common goal. As you know, France and Belgium are part of an international coalition against ISIS, and ISIS has claimed responsibility for the terrorist attacks. There are several reasons for the terrorist attacks. First, Islamists want to sow panic among the population, because it is known that fear, chaos and anarchy are favorable conditions for a coup.

French Muslims say that ISIS and Islam cannot be equated, but one example is needed. It is worth mentioning "Charlie Hebdo". This is a fairly wellknown French magazine that is published weekly. On March 1, 2006, the magazine published the so-called Manifesto of the Twelve. The manifesto proclaimed Islamism a new totalitarianism after fascism, Nazism and Stalinism. On January 7, 2015, there was an armed attack on the editorial office, killing 12 people. And before that, the magazine published a special issue with a caricature of the Prophet Muhammad. Thousands of Muslims around the world expressed their outrage, which also resulted in terrorist attacks in Paris and Brussels.

In addition to the infiltration of terrorists into Europe and their series of terrorist attacks, the massive influx of refugees has resulted in an increase in crime and increased danger in stable and safe European cities. Incidents of attacks on local women in Germany, including New Year's Eve 2016 in Cologne, have become widespread. According to police, as of January 5, 2016, 90 cases of assault were known, including 15 women reporting harassment and one rape complaint. In addition, the victims said that the attackers took their bags, mobile phones and wallets. A group of 1,000 men of "North African" or "Arab" appearance joined the crowd, celebrating a "hunt for women". By January 12, the city police had received more than 650 reports.

The Federal Criminal Police Office of Germany has promised to study the phenomenon of "tahkharush", which in Arab countries means collective sexual harassment: young men surround a woman, start shouting obscene things, try to touch and take away personal belongings. Such cases were reported, for example, during the revolution in Egypt, where female correspondents in Tahrir
Square were harassed. No such incidents have been reported in Germany so far.

In addition to Cologne, similar incidents took place in other cities in Germany (Berlin, Hamburg, Dusseldorf, Stuttgart), as well as in Switzerland (Zurich) and Austria (Salzburg). In general, this situation is a failure of the policy of uncontrolled reception of refugees and migrants [32].

With the increase in the number of illegal migrants and refugees at the European borders in 2015, the issue of border control between the EU and individual European countries became acute. Some countries have reacted sharply to the situation, disagreeing with EU recommendations on the reception of refugees. For example, Hungary has closed its southern borders with Serbia and Croatia to stem the flow of migrants. Moreover, by order of the Prime Minister of Hungary, Viktor Orbán, a $175 \mathrm{~km}$ long wall was built along the border with Serbia and Croatia.

Given the discussions that have been going on since the beginning of 2015 , as well as the decisions taken in 2016 (including the conclusion of a relevant agreement with Turkey), the most likely course of events will concern security and border sealing, as well as the transfer of responsibility for in need of protection, for states bordering the EU.

However, the question arises: are there any chances for the success of closing borders, attempts to prevent new refugees from entering the EU, humanitarian aid to refugees in third countries (the so-called first asylum countries)? The answer is no. To ensure their security, the leadership of the EU and EU Member States are implementing procedures to return refugees home or to third countries, preventing the arrival of new asylum seekers on their territory. In fact, this will lead to the transfer of the crisis to the next states and even regions, and as a result - to the deprivation of security of subsequent communities and further destabilization of the international situation. This is how threats spread to a new "circle" of countries.

Paradoxically, the idea of suspending the Schengen area regime, closing the borders in order to protect their territories from the influx of immigrants, only creates the illusion of security for member states. Again, even if the influx of people into the European Union is stopped, such actions do not guarantee security - immigrants arriving in neighboring EU countries will still destabilize the situation in the region, and the effects of their stay in neighboring countries will be felt in the EU. It should also be borne in mind that the closure of the territory of the Member States for asylum seekers is contrary to the obligations under the Convention relating to the 
Status of Refugees (1951), to which the EU Member States are signatories [ 55].

Conclusions. The system of cooperation between states within the European Union and the Council of Europe on refugees and migration in general is the most developed. This is ensured by the combination of EU and Council of Europe migration law, which allows more or less control over the flow of refugees, asylum seekers and illegal migrants, to define unified decision-making procedures for granting refugee status and asylum, to cooperate with as many continents to join forces to address any refugee issues. At the same time, this system was not ready for a mass influx of refugees.

\section{References:}

1. Namoniuk Ch. I. Mihratsiina kryza yak zahroza politychnii yednosti derzhav Yevrosoiuzu. Mizhnarodni vidnosyny. Seriya "Politychni nauky". 2015. № 9. URL: http://journals.iir.kiev.ua/index.php/pol_n/article/ view/2643/2349.

2. Napady na zhinok u Nimechchyni. 2016. Vikipediia : website. URL: https://bit.ly/2FB5r55.

3. Nimechchyna vytratyt za chotyry roky $€ 78$ mlrd na potreby bizhentsiv. URL: https://zaxid.net/nimechchina vitratit_za chotiri_roki_78_mlrd_na_potrebi_bizhentsiv_n1457097.

4. $\bar{P}$ Polityka Nimechchyny shchodo bizhentsiv staie dedali zhorstkishoiu. URL: https://glavcom.ua/digest/ politika-nimechchini-shchodo-bizhenciv-staje-dedali-zhorstkishoyu-514715.html.

5. Problema bizhentsiv v YeS: Yaki varianty proponuiut yevroskeptyky. URL: https://ua.112.ua/statji/ problema-bizhentsiv-v-yes-yaki-varianty-proponuiut-ievroskeptyky-383004.html.

6. Tramp rozkrytykuvav polityku Merkel shchodo bizhentsiv. RBK-Ukraina : website. URL: https://www.rbc.ua/ukr/news/tramp-raskritikoval-politiku-merkel-otnoshenii-1529332790.html.

7. U Nimechchyni partner Merkel proponuie svoiu vidstavku cherez polityku shchodo immihratsii. Radio "Svoboda" : website. URL: https://www.radiosvoboda.org/a/news/29331407.html.

8. Fitisova A., Solodko A. Mihratsiina kryza v YeS: statystyka ta analiz polityky. Analitychnyi tsentr CEDOS : website. URL: https://cedos.org.ua/uk/articles/mihratsiina-kryza-v-yes-statystyka-ta-analiz-polityky.

9. Chuienko V. Yevropeiska kryza bizhentsiv yak naiaktualnisha problema Yevropeiskoho Soiuzu. National Law Journal: Teory and Practice. 2016. № 8. URL: http://www.jurnaluljuridic.in.ua/archive/2016/4/46.pdf.

10. Shalenna N. Osoblyvosti formuvannia kontseptu "ievropeiskoho islamu". Actual problems of international relations. 2014. Vol. 1. № 123. URL: http://journals.iir.kiev.ua/index.php/apmv/article/view/2856.

11. Iuskiv B. Kryza mihratsiinoi systemy Yevropeiskoho Soiuzu. Naukovyi visnyk Skhidnoievropeiskoho natsionalnoho universytetu im. L. Ukrainky. Seriya "Mizhnarodni vidnosyny". 2016. № 2 (327). S. 48-54.

12. A Common Immigration Policy for Europe : Principles, actions and tools. Brussels : Commission of the European Communities, 2008. 18 p. URL: https://eur-lex.europa.eu/LexUriServ/LexUriServ.do?uri=COM: 2008:0359:FIN:EN:PDF.

13. Global Compact for Safe, Orderly and Regular Migration. UN. URL: http://undocs.org/en/A/CONF.231/3

14. Interactive map: main routs of migration in Europe. ArcGIS Online. URL: https://bit.ly/2RN3qcw.

15. Regulation (EU) № 604/2013 of the European Parliament and of the Council of 26 June 2013 establishing the criteria and mechanisms for determining the Member State responsible for examining an application for international protection lodged in one of the Member States by a third-country national or a stateless person (recast). Official Journal of the European Union. 2013. L 180. URL: http://eur-lex.europa.eu/LexUriServ/ LexUriServ.do? uri=OJ:L:2013:180:0031:0059:EN:PDF.

\section{Подрєз Ю.В., ЯрОШ Н.В. МІГРАЦІЙНА ПОЛІТИКА КРАЇН - ЧЛЕНІВ ЄВРОПЕЙСЬКОГО СОЮЗУ ЩОДО ВРЕГУЛЮВАННЯ ПРОБЛЕМ ІЗ ПРИЙОМУ БІЖЕНЦІВ ПРОТЯГОМ 2015-2016 РОКІВ}

У статі розглянуто політичні наслідки міграчійної кризи 2015-2018 років для країн - членів Європейського Союзу, яка спричинена масовим напливом мігрантів у Свропу з охоплених війнами країн Африки і Близького Сходу. Ї̈ наслідки певним чином потенційно загрожують єдності Європейського Союзу та можуть негативно вплинути на прочес європейської інтеграції. Головна увага в дослідженні приділена аналізу власної міграційної політики краӥн - членів Свропейського Союзу щэодо врегулювання проблем із прийомом біженців (Німеччина, Угорщина, Франція, Данія, Нідерланди тощо), що призвело до локальних політичних конфліктів і суперечностей. Більшість держав намагаються своїми діями обмежити ризики, пов'язані з міграцією. Стратегічно иі дії фактично зводяться до трьох моментів: ефективної охорони кордонів, контролю припливу іноземиів до країни, а також адекватної інтеграчійної політики.

Аналіз міграційної політики безпосередньо країн Європейського Союзу щьоо біжениів протягом зазначеного нами періоду свідчить про різку зміну ставлення місиевого населення - від політики 
відчинених дверей до закриття кордонів. Система співробітництва держсв у рамках Європейського Союзу та Ради Свропи щодо біженців та мігращії загалом є найбільи розвиненою. Сукупністю права Європейського Союзу та Ради Європи у сфері міграції дозволяє більш-менш контролювати потоки біженців, шукачів притулку та нелегальних мігрантів, визначати уніфіковані процедури ухвалення рімень щзодо надання статусу біжения та реалізаиії його права на притулок, співпрацюювати з максимально можливою кількістю держав Європи з метою об'єднання зусиль для вирімення будь-яких питань, що стосуються біженців. Це, на нашу думку, зумовлено зростанням кількості осіб, що прибувають, суперечками про природу спостережуваних міграчійних потоків, а також страхом перед ісламізацією, зростанням злочинності і терористичними загрозами.

Ключові слова: міграџія, мігращійна політика, Свропейський Союз, міграџійна криза, біжениі. 